We thank the Science Research Council for support of these and related studies.

R. D. GILLARD

E. D. MoKEnzIE

R. MASON

G. B. ROBERTSON

Department of Chemistry,

University of Shoffield,

and

School of Molecular Sciences,

University of Warwick.

Hay, R. W., Rev. Pure App. Chem., 13, 157 (1903).

${ }^{2}$ Smith, E, L,, J, Riol. Chem., 173, 571 (1948).

${ }^{3}$ Gilbert, T. B., Otcy, M. C., and Price, V. E., J. Biot. Chem.,190, 377 (1951).

4 Tanford, C., Kirk, P. C., and Chantooni, M. K., J. Amer. Chem. Soc., 76, 5325 (1954).

- Caglioti, V., Silvestroni, P., and Furlani, C., J. Tnorg. Nuel. Chenn, 13, 95 (1960).

'Strandberg, B., Lindquist, I., and Rosenstein, R., Zeit. f. Kristalog., 116,
$\mathbf{8 5 5}(1961)$.

'Hughes, E. W., and Moore, W. J., J. Amer. Chem. Soc., V1, 2618 (1949).

\section{Reactivity of Aromatic Compounds towards Hydrogen Atoms}

THE reactivity of aromatic compounds toward hydrated electrons and hydroxyl radicals has been the subject of various recent investigations ${ }^{1,2}$. The effects of substituents on the reactivities of benzone and benzoste ion were correlated with the substituent constant $(\sigma)$ of Hammett's equation. It has been shown that the mechanism of attack of hydroxyl radicals on aromatic compounds is analogous to electrophilic aromatic substitution ${ }^{2}$. On the other hand, the reactions of hydrated electrons followod a pattern analogous to nuclcophilic substitution. The reactivity of uromatic compounds toward hydrogen atoms was invostignted in order to study the nature of the $\mathrm{Ph} X+\mathrm{H}$ reaction.

The specific rate constants of substituted benzones with hydrogen atoms were determined by competition kineties, using isopropanol as the compoting compound. De-aerated solutions containing $5 \times 10^{-2} \mathrm{M}$ isopropanol, $1 \times 10^{-3} \mathrm{M}$ acotono (as $e_{2}$ scavenger in order to avoid the $e_{a, \mathrm{a}}^{-}+\mathrm{PhX}$

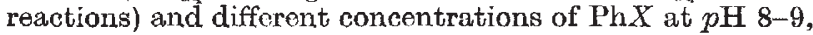
were irrudiated in a cobalt-60 $\gamma$-sourco $\left(4 \times 10^{17} \mathrm{eV} \mathrm{g} \mathrm{g}^{-1}\right.$ $\left.\mathrm{min}^{-1}\right)$. Tho doses of irradiation were $8-40 \times 10^{17} \mathrm{eV} \mathrm{g} \mathrm{g}^{-1}$. The yield of hydrogen was determined by gas chromatography (on a column of 'molecular sieves' 5 A). Each experiment was repeated at least eight times and the coefficient of variation was \pm 10 per cent.

Under the experimental conditions the hydrated olectrons react with ncetone, whereas the hydroxyl radicals react with isopropanol. Hydrogen atoms may react with isopropanol to form hydrogen, or with $\mathrm{PhX}$ to form PhXH radicals, which do not yield hydrogen ${ }^{8}$. The experimental yiold of hydrogen is therefore tho sum of the 'molecular' yield $G \mathrm{H}_{2}$ and of $G\left(\mathrm{H}+\right.$ isopropanol). $G \mathrm{H}_{\mathbf{z}}$ was determined undor similar conditions using a solution of $1 \times 10^{-3} \mathrm{M}$ potassium bromide. The sum of $G_{\mathrm{H}}$, and $G_{\mathrm{H}_{2}}$ the total yield of hydrogen atoms, was determined using a solution of $5 \times 10^{-2} \mathrm{M}$ isopropanol $+1 \times 10^{-3} \mathrm{M}$ acetone. Using these values and the known value of the specific rate constant for the reaction of hydrogen atoms with isopropanol, $k_{\mathrm{H}}+$ isopropanol $=5.0 \times 10^{7} \mathrm{M}^{-1} \mathrm{sec}^{-1}$ (ref. 4), the rate constant of the reaction $\mathbf{H}+\operatorname{Ph} X$ was calculated: $k_{\mathrm{H}}+\mathbf{P h} \boldsymbol{X}=$

$\underline{k_{\mathrm{H}}+\text { isopropanol }}\left[G_{\mathrm{H}}-G(\mathrm{H}+\right.$ isopropanol $\left.)\right]$ [isopropanol]

$$
G(\mathrm{H}+\text { isopropanol })[\mathrm{Ph} X]
$$

The results are summarized in Tablo 1 . The order of reactivity is $\mathrm{PhSO}_{3}^{-}<\mathrm{PhCN}^{\prime}<\mathrm{PhNHCOCH}_{3}<\mathrm{PhCH}_{2}$ $\mathrm{COO}^{-}<\mathrm{PhCOO}^{-}<\mathrm{PhCOCH}_{3}<\mathrm{PhNO}_{2}<\mathrm{PhNH}_{2}<$ PhOH. This order is in fair agreoment with the order of reactivity of these compounds toward electrophilic aromatic substitution, with one exception: the reactivity of nitrobenzene is much highor than would be expected from the general behaviour of aromatic substitution. This

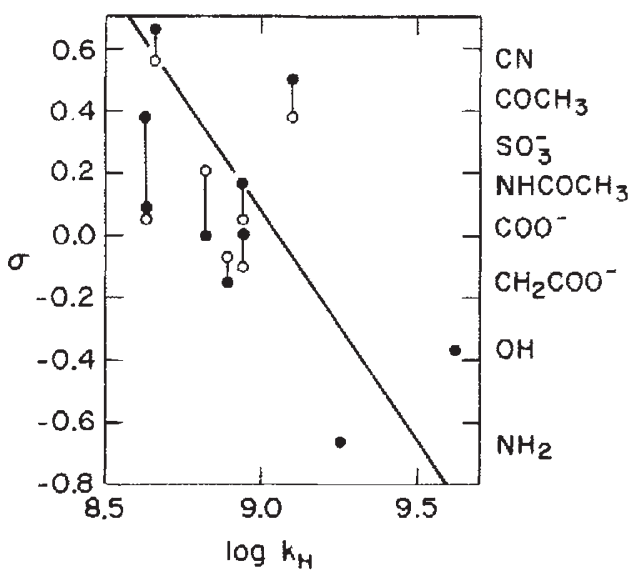

Fig. 3. Plot of $\log k_{\mathrm{H}}+\operatorname{Ph} x$ against o

is most probably duo to a direct attack by hydrogen atoms on the $\mathrm{NO}_{2}$ group, as may be inferred from their fast reaction rates with $\mathrm{NO}_{2}^{-}$ion ${ }^{5,6}$ and $\mathrm{C}\left(\mathrm{NO}_{2}\right)_{4}$ (ref. 7).

Table 1. Reactivity of aromatio Compodnds towards Hydrogha

\begin{tabular}{|c|c|}
\hline Compound & Rate constant $\left(\mathrm{M}^{-1} \mathrm{sec}^{-1}\right)$ \\
\hline 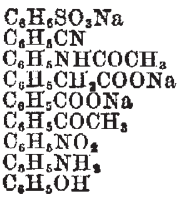 & $\begin{array}{l}4.30 \times 10^{8} \\
4.53 \times 10^{8} \\
6.70 \times 10^{8} \\
7.70 \times 10^{8} \\
8.70 \times 10^{8} \\
1.26 \times 10^{8} \\
1.66 \times 10^{9} \\
1.76 \times 10^{8} \\
4.20 \times 10^{9}\end{array}$ \\
\hline
\end{tabular}

A quantitative treatment of the results is shown in Fig. 1, where $\log k_{\mathrm{H}}+\mathrm{Ph} X$ is plotted against Hammett's $\sigma$ valucs (takon from refs. 8 and 9 ). Both $\sigma_{m}$ and $\sigma_{p}$ values were taken for substituents having a deactivating effect, but only the $\sigma_{p}$ values were taken for the other substituents. (The attack by hydrogen atoms on aromatic compounds is electrophilic in nature, thus their attack on the meta position of aromatic compounds carrying ortho-para directing substituents can be neglected.) A $\sigma$ value similar to that of $\mathrm{CH}_{2} \mathrm{CH}_{\mathbf{3}}$ and $\mathrm{CH}_{2} \mathrm{CH}_{2} \mathrm{COO}^{-}$groups was taken for the $\mathrm{CH}_{2} \mathrm{COO}^{-}$group. Neglecting the value for nitrobenzeno, which is unexpectedly high, as explained before, a straight line could be drawn with a slopo = $-0 \cdot 7$, which demonstrates the electrophilic nature of the attack of hydrogen atoms on aromatic compounds. The absolute value of $\rho=-0.7$ is higher than that observed for the reaction of hydroxyl radicals $(p=-0.41)$ (ref. 2). This is in accordance with the relatively lower reactivity of hydrogen atoms, which makes them more selective.

The electrophilic behaviour of hydrogen atoms in the $\mathrm{H}+\mathrm{PhX}$ reaction is not surprising, since a higher electron density on the aromatic ring promotes the formation of the new $\mathrm{C}-\mathrm{H}$ bond and stabilizes the $\mathrm{PhXH}$ radical formed.

\section{ANBar \\ D. MEYerstein \\ P. NETA}

The Weizmann Institute of Science and the Soroq Nucloar Research Centre, Rohovoth, Isracl.

1 Anbar, M., and Hart, T. J., $J$. Amer. Chem. Soc., 86, 5638 (1964).

${ }^{2}$ Anbar, M., Meyerstein, D., and Neta, P., J. Amer. Chem. Soc. (In the press). ${ }^{3}$ Anbar, M., Israel $A E C$ Ann. Rep. (1065).

-Appleby, A., Scholes, G., and Simic, M., J. Amer, Chem. Soc., 85, 3891 (1963).

"Rabani, J., and Steln, G., J. Chem. Phys., 37, 1865 (1962)

в Hayon, E., and Morcau, M., J. Chim. Phys., 391 (1965).

'Rabani, J., Mulac, W.A., and Matheson, M.S., J. Fhys. Chem., 69, 53 (1065).

Hine. J., Physical Organic Chemistry (McGraw-Hill Book Co., Inc., New York, X.Y., 1062).

${ }^{9}$ Van Bekkum, H., Verkade, P. E., and Wepster, B. M., Rec. Trav. Chim, 